Article

\title{
Toward Sustainability: Novelties, Areas of Learning and Innovation in Urban Agriculture
}

\author{
Ina Opitz ${ }^{1,2, *}$, Kathrin Specht ${ }^{1,2}$, Regine Berges ${ }^{3}$, Rosemarie Siebert ${ }^{1}$ and Annette Piorr ${ }^{1}$ \\ 1 Leibniz Centre for Agricultural Landscape Research, Institute of Socio-Economics, Eberswalder Straße 84, \\ Müncheberg 15374, Germany; kathrin.specht@zalf.de (K.S.); rsiebert@zalf.de (R.S.); apiorr@zalf.de (A.P.) \\ 2 Faculty of Life Sciences, Humboldt University of Berlin, 10099 Berlin, Germany \\ 3 agrathaer GmbH, Eberswalder Str. 84, 15374 Müncheberg, Germany; regine.berges@agrathaer.de \\ * Correspondence: ina.opitz@zalf.de; Tel.: +49-33432-82-419
}

Academic Editor: Tan Yigitcanlar

Received: 29 February 2016; Accepted: 5 April 2016; Published: 12 April 2016

\begin{abstract}
Given the search for new solutions to better prepare cities for the future, in recent years, urban agriculture (UA) has gained in relevance. Within the context of UA, innovative organizational and technical approaches are generated and tested. They can be understood as novelties that begin a potential innovation process. This empirical study is based on 17 qualitative interviews in the U.S. (NYC; Philadelphia, PA, USA; Chicago, IL, USA). The aim was to identify: (i) the most relevant areas of learning and innovation; (ii) the drivers of innovation; (iii) the applied novelties and their specific approach to overcoming the perceived obstacles; (iv) the intrinsic challenges that practitioners face in the innovation process; and (v) the novelties' potential to contribute to sustainability and societal change. As the results of the study demonstrate, learning and innovation in UA occur predominantly in four areas, namely, "financing and funding", "production, technology and infrastructure", "markets and demands" and "social acceptance and cultural learning". The described novelties include approaches to enhance the positive impacts of practicing agriculture within urban areas, and some of them have the potential to contribute to societal change and open up opportunities for social learning processes.
\end{abstract}

Keywords: societal change; drivers of innovation; intrinsic challenges; urban farming; qualitative interviews

\section{Introduction}

Worldwide, cities are facing the challenges of global megatrends, such as population growth, increasing urbanization and climate change. Given the search for new solutions to better prepare cities for the future, in recent years, urban agriculture (UA) has moved from an issue at the edge of public discourse to its center $[1,2]$.

UA practices range from family home-based food gardens to community-based farming to commercial flagship projects that use high-technology products [3-5]. UA is defined as "an industry located within or on the fringe of a town, city or metropolis, which grows or raises, processes and distributes a diversity of food and non-food products" [6,7]. As Opitz et al. 2015 describe, UA is a system with certain spatial, ecological, social and economic characteristics, e.g., size and location, legal status, agricultural techniques, stakeholders and organizational practices. UA is adapted to urban conditions, and UA practitioners' actions are based on the resources in the urban setting $[8,9]$. Often utilizing vacant lots or other abandoned places within the neighborhood, urban gardeners are confronted with specific conditions that are distinct from those that farmers in rural areas face, e.g., the risk of soil contamination $[9,10]$, limited access to water sources or higher costs for water $[9,11]$. 
Additionally, most UA initiatives lack access to credit or investment schemes $[9,12,13]$, have limited land use rights $[4,9,13,14]$ or experience vandalism and theft $[9,15]$.

Within the context of UA, innovative ideas regarding new organizational and technical approaches are generated and tested. In recent literature, a large group of studies described and evaluated examples of best practices [16] with the aim of stimulating replication in other localities [17] or demonstrating the wide range of management approaches addressing polluted or insufficient soil and water resources [18-20], waste recycling [21,22] and concepts of micro-level entrepreneurial agriculture [23,24]. A second group of studies addresses the general potential of technical innovations, such as rooftop gardens [25], rooftop greenhouses [26-28] and vertical farming [29-31], in urban contexts. Specht et al. $(2014,2015)$ and Thomaier et al. 2015 describe the benefits and limitations of agriculture in and on urban buildings [5,32,33]. A few studies, the third group of articles, analyze the resource needs in urban agriculture $[9,13]$ and analyze innovations occurring as a response to these needs [9]. Thereby, Pfeiffer et al., 2014 focus predominantly on technical innovations or techniques improving and diversifying agricultural production in urban settings [9].

From the perspective of innovation research, such approaches can be understood as novelties given that any successful change in production, consumption or distribution routines can be considered a novelty [34]. A novelty stands at the beginning of a potential innovation process. It is an idea or a kind of prototype that is adopted or adapted and becomes an innovation when the idea is matured, diffused into society and widely known. In terms of non-technological innovations, a novelty can be the starting point of a societal transition $[35,36]$. Novelties can result from an individual learning process, whereby an individual takes information from his or her own context to assess the given situation, starts a process of searching for solutions to a problem and eventually generates a novelty [35]. By contrast, in a social learning process, societal groups use shared cognitive capabilities and resources within a network to foster a novelty to initiate societal transition [35]. A novelty is a "new way of doing or thinking - a new mode that carries the potential to do better" [34].

Aspirations to improve performance are widespread within the UA community. At the individual level, gardeners mention that the most important motivation for practicing UA is access to fresh and better food [37-39]. However, as found in various studies, value-led motivations, e.g., educating young people and reconnecting the neighborhood's residents to nature [40], integrating migrants [41] or building local food networks to improve food security [42], are also relevant to gardeners' decision to participate in UA communities.

Against the backdrop of the limitations in practicing UA in urban settings and the common wish to contribute to societal change, our guiding hypothesis is as follows: learning processes in UA aim to solve problems in the practice of UA and take place at the individual level. Additionally, some of the novelties contribute to sustainability and have the potential to initiate societal transition.

This empirical study, which conducted qualitative interviews in the U.S., aims to identify: (i) the most relevant areas of learning and innovation; (ii) the drivers of innovation; (iii) the applied novelties and their specific approach to overcoming the perceived obstacles; (iv) the intrinsic challenges that practitioners face in the innovation process; and (v) the novelties' potential to contribute to sustainability and societal change.

\section{Materials and Methods}

\subsection{Selection of Interview Sites}

When selecting the sites, we considered the following conditions: local climate, city development and municipal UA policy, which influence growing conditions and innovation activities within the local UA community. For example, shrinkage or growth of a city strongly influences the availability of land for UA, leading to specific innovative adaptation strategies. To obtain a broader picture and to minimize the impact of local conditions, we conducted interviews in three different U.S. cities, which were selected based on the following criteria: 
i presence of different forms of UA (social and entrepreneurial)

ii presence of innovative UA activities (documented in the literature/on the Internet)

iii presence of one or more city-wide UA support organization(s) and/or municipal activities acknowledging UA

Our pre-study, based on an Internet and literature search, revealed that NYC, Chicago and Philadelphia met the abovementioned criteria [13,43-46]. An overview of population estimates, UA types, municipal policies and funding schemes in the selected cities is presented in Table 1.

Table 1. Differences and similarities between NYC, Chicago and Philadelphia regarding UA types, estimated numbers of gardens or farms, municipal funding schemes and availability of supporting organizations.

\begin{tabular}{|c|c|c|c|}
\hline & New York City & Chicago & Philadelphia \\
\hline $\begin{array}{l}\text { Local climate } \\
\text { (Köppen climate } \\
\text { classification system) }\end{array}$ & $\begin{array}{l}\text { humid } \\
\text { subtropical/continental }\end{array}$ & humid continental & humid subtropical \\
\hline $\begin{array}{l}\text { Land area in square } \\
\text { miles, } 2010\end{array}$ & 303 & 228 & 134 \\
\hline $\begin{array}{l}\text { Population estimates } \\
\text { in millions, } 2014\end{array}$ & 8.5 & 2.7 & 1.6 \\
\hline $\begin{array}{l}\text { Population per } \\
\text { square mile, } 2010\end{array}$ & 27,000 & 11,800 & 11,400 \\
\hline UA types & $\begin{array}{l}\text { Community gardens and } \\
\text { urban farms, flagship } \\
\text { projects (high-technology to } \\
\text { large-scale commercial) }\end{array}$ & $\begin{array}{l}\text { Community gardens and } \\
\text { urban farms, aquaponics } \\
\text { production, food } \\
\text { production indoors } \\
\text { and rooftops }\end{array}$ & $\begin{array}{l}\text { Community gardens and } \\
\text { urban farms, hydroponic } \\
\text { production }\end{array}$ \\
\hline $\begin{array}{l}\text { Estimated number of } \\
\text { urban community } \\
\text { gardens and farms }\end{array}$ & $\begin{array}{l}\text { About } 1000 \text { community } \\
\text { gardens and farms; some } \\
\text { non-profit and } \\
\text { commercial farms }\end{array}$ & $\begin{array}{l}\text { 600-700 community } \\
\text { gardens }\end{array}$ & $\begin{array}{l}226 \text { community or squatter } \\
\text { gardens; (declined from 500) }\end{array}$ \\
\hline UA policies & $\begin{array}{ll}\text { - } & \text { Strategic and policy } \\
\text { plans (PlanNYC, } \\
\text { FoodWorks, etc.) } \\
\text { - Municipal programs } \\
\text { (e.g., Green Thumb, } \\
\text { Housing Authority's } \\
\text { Garden and Greening } \\
\text { Program, etc.) }\end{array}$ & $\begin{array}{ll}\text { - } & \text { Integration of UA in } \\
\text { urban planning } \\
\text { (zoning ordinance) } \\
\text { - } \quad \text { Municipal programs } \\
\text { (Chicago Park } \\
\text { District's } \\
\text { Community Gardens) } \\
\text { - } \quad \text { Food Policy Council }\end{array}$ & $\begin{array}{ll}\text { - } & \text { Strategic plan } \\
\text { (Philadelphia } \\
\text { Food Charter) } \\
\text { - Decline in support for } \\
\text { community gardens } \\
\text { from the } \\
\text { mid-1990s-2008 }\end{array}$ \\
\hline $\begin{array}{l}\text { Municipal UA } \\
\text { funding schemes }\end{array}$ & $\begin{array}{l}\text { Municipal grants for certain } \\
\text { projects, e.g., rooftop farms }\end{array}$ & None known & None known \\
\hline $\begin{array}{l}\text { Supporting } \\
\text { environment }\end{array}$ & $\begin{array}{ll}- & \text { Many supporting } \\
\text { NGOs or trusts } \\
-\quad \text { Strong } \\
\text { supporting environment }\end{array}$ & $\begin{array}{ll}\text { - } & \text { Citywide UA network } \\
\text { - } & \text { Moderate supporting } \\
\text { environment }\end{array}$ & $\begin{array}{ll}\text { - } & \text { One statewide } \\
& \text { organization } \\
\text { - } & \text { Weak supporting } \\
\text { environment }\end{array}$ \\
\hline
\end{tabular}

Different forms of UA exist in each of these cities, from community gardens to urban rooftop farms. Several organizational (e.g., education programs, common gardening approaches), economic (e.g., distribution model, financing model) or technical (e.g., rooftop farming, aquaponics production) innovations were identified. Furthermore, we found that various stakeholders, from NGOs to municipal officials, work on innovative concepts to promote and maintain UA at the city level. Structural differences exist between the cities in terms of city development (growing, shrinking, transformation processes). NYC is a growing metropolis [14,47]; Philadelphia is losing inhabitants [48]; and Chicago is undergoing transformation processes [49]. In Chicago, an area of $264,181 \mathrm{~m}^{2}$ is dedicated to urban food production (e.g., community or residential gardens) [44]. Kremer and DeLiberty 
(2011) report that UA activities in Philadelphia are concentrated in economically-disadvantaged neighborhoods [50]. The situation in NYC is quite different. In NYC, in addition to community gardens and farms, several flagship projects that apply high-technology production to large-scale commercial UA can be found [40]. NYC is one of the most densely-populated U.S. cities and has some of the nation's highest land values. Unsurprisingly, most of the over 1000 community gardens in NYC are located in low-income areas [10].

\subsection{Empirical Basis and Data Analysis}

The results are based on the analysis of 17 qualitative interviews conducted in 2012 with persons working in the context of UA in NYC, Chicago or Philadelphia. Interview partners were selected to cover the broad field of innovation agents, including those developing, adapting or promoting innovations in UA, namely gardeners and farmers, NGOs and governmental entities or programs. To gain a more neutral, overall perspective of the situation of UA and innovation, we also interviewed local researchers.

For the current study, we interviewed single individuals or representatives of organizations and UA businesses who were considered to be leaders in UA; an overview of the interviewees is presented in Table 2. The people who shape and influence UA development are affiliated with environmental or educational NGOs, social work, public administration or planning authorities. A second group also contains business entrepreneurs (e.g., in the field of rooftop farming), who are described as charismatic leaders who receive substantial public attention and, thus, make UA visible. The group of interviewees is supplemented by leading researchers in the field of UA. The interviewees' connection to UA in practice, support or research and the type of innovation that is applied in the organization, farm or garden are listed in Table 2.

Guided interviews that lasted approximately $60 \mathrm{~min}$ were conducted with the experts [51]. The interviewees were asked about the situation surrounding UA in their city, their specific work and the UA innovation process. The interviews were recorded, transcribed and coded using MAXQDA software [52]. We applied the principles of qualitative content analysis described by Kuckartz 2014 [53]. 
Table 2. Overview of the interviewees, their institutional background and connection to UA and the innovations applied in their project.

\begin{tabular}{|c|c|c|c|c|c|c|c|}
\hline & Institution & Interviewee & $\begin{array}{c}\text { UA } \\
\text { Practice }\end{array}$ & $\begin{array}{c}\text { UA } \\
\text { Support }\end{array}$ & $\begin{array}{c}\text { UA } \\
\text { Research }\end{array}$ & $\begin{array}{l}\text { Types of Novelties Applied in } \\
\text { NGO, Farm or Garden }\end{array}$ & No. \\
\hline \multirow{5}{*}{ New York City } & University, urban planning & Researcher & & & $x$ & & $\# 1$ \\
\hline & Conservation agency & NGO representative & & $\mathrm{x}$ & & organizational & \#2 \\
\hline & Governmental community gardening program & Representative & & $\mathrm{x}$ & & organizational, technical & \#3 \\
\hline & Community garden & Representative & $\mathrm{x}$ & & & organizational & \#4 \\
\hline & Rooftop garden & Member of management & $\mathrm{x}$ & & & organizational, technical & $\# 5$ \\
\hline \multirow{7}{*}{ Philadelphia } & UA enterprise/start-up business & Member of management & & $\mathrm{x}$ & & organizational & \#6 \\
\hline & Urban farm & Member of management & $\mathrm{x}$ & & & organizational, technical, economic & \#7 \\
\hline & University, politics & Researcher & & & $\mathrm{x}$ & & \#8 \\
\hline & Community gardening program & NGO representative & & $\mathrm{x}$ & & organizational & \#9 \\
\hline & Community gardens/farm & NGO representative & $\mathrm{x}$ & & & organizational & $\# 10$ \\
\hline & Urban farm & Member of management & $\mathrm{x}$ & & & technical & $\# 11$ \\
\hline & Community garden & NGO representative & $x$ & & & technical & $\# 12$ \\
\hline \multirow{5}{*}{ Chicago } & Urban agriculture network & NGO representative & & $\mathrm{x}$ & & organizational & \#13 \\
\hline & Urban farm/social enterprise & Member of management & $\mathrm{x}$ & & & organizational, technical, economic & $\# 14$ \\
\hline & Urban farm/food business start-up & Member of management & $\mathrm{x}$ & & & technical & $\# 15$ \\
\hline & Public planning authority & Representative & & $\mathrm{x}$ & & organizational & \#16 \\
\hline & Urban farm & Member of management & $\mathrm{x}$ & & & economic, technical & $\# 17$ \\
\hline
\end{tabular}




\section{Results}

The primary areas of learning and innovation in UA identified from the interviews are as follows: (1) financing and funding; (2) production, technology and infrastructure; (3) market and demands; and (4) social acceptance and cultural learning. Analyzing the interviews, we identified several obstacles that drive the search for solutions through the adoption and generation of novelties in the areas of learning. Those are described in the paragraphs entitled "drivers of innovation and learning" for each area. The novelties mentioned in the interviews were matched to the areas of learning and described in terms of their specific approach to overcoming the obstacles. Complementarily, paragraphs on intrinsic challenges in certain areas are presented below. Intrinsic challenges describe the challenges of UA practitioners, which have not been solved so far by the mentioned innovations.

\subsection{Financing and Funding}

Drivers of innovation and learning: One major topic in the area of learning and adopting innovation is how to access financing and funding resources and successfully apply for grants. The majority of UA projects are struggling for economic viability. Only a small number of (business-oriented) UA projects are initiated by professional start-ups, which pool academic and business experience to access loans and grants for their activities. For the majority of UA projects, from small community gardens to flagship indoor farms, financing is a key challenge that is solved through different solutions.

Innovations and novelties: Alternative funding and fundraising approaches are increasingly important for both business-oriented and non-profit UA compared to classical funding (bank credit, federal money, city grants, etc.). These approaches involve many donors and sources of funding that provide money for certain projects and events of a farm or garden. Table 3 presents the novel products mentioned in the interviews.

Table 3. Innovations and novelties in the learning area "financing and funding".

\begin{tabular}{ll}
\hline \multicolumn{1}{c}{ Innovation/Novelty } & \multicolumn{1}{c}{ Description } \\
\hline Kickstarter.com (\#1) & $\begin{array}{l}\text { International online funding platform on which creative project } \\
\text { creators can attract several mini-donations from supporters }\end{array}$ \\
\hline New York funding platform (\#3) & $\begin{array}{l}\text { Free online funding platform for environmental projects located } \\
\text { in New York City }\end{array}$ \\
\hline
\end{tabular}

Approaches and aims of the novelties: It is advantageous for UA projects to utilize funding platforms because such platforms face fewer difficulties with administration, and money can be invested more independently. These approaches can be useful for obtaining small amounts of money, e.g., when applying for funds would not justify the expenditure of time or, as in many cases, municipal funding schemes are not available. An NGO representative stresses the importance of online fundraising, as follows:

"Fundraising online is huge now. ( . . ) A lot of gardens have raised money to buy tools, small things that you ordinary wouldn't write a grant for. That's been a big difference. The gardeners are way more independent now." (\#3)

Intrinsic challenges of financing and funding: Interviewees from different backgrounds identify disparities based on race and class in financing and funding in the UA system.

"People kept telling us that more developed white-led organizations tend to have greater access to those resources. Some farms and gardens are able to raise hundred-thousands of dollars a year, and others have to have plant sales to raise a few hundred dollars to buy some tools. I think that's a really important problem in the UA community." (\#1)

When asked about intrinsic challenges, the interviewees often raised the issue of competition between different approaches to UA. The interviewees observe that the media and the public view certain 
forms of UA (e.g., rooftop gardens) as being very innovative. This approach creates tension within the UA community because people realize that these entrepreneurs receive more attention. Some label the high level of interest in these projects as "hype" and consider that most of the "common" UA projects are barely noticed.

"Everybody is coming to New York to visit. They want to see the rooftop farms. He [the operator] is the perfect example of a young, white, hip person who is able to get New York Times articles written and grants to create a new rooftop farm. That drives other farmers and gardeners crazy in New York because they realize it. He is this demographic that is trendy now and that's why he is actually getting access—-to the buildings, to funding." (\#1)

Moreover, as another interviewee stresses, some innovations are fundamentally based on funding. In these cases, funding influences the direction and the strength of innovation processes.

"I also think that there are certain things that happen because there is funding for it.

Funding-driven changes are definitely big." (\#3)

\subsection{Production, Technology and Infrastructure}

Drivers of innovation and learning: When starting a professional urban farm or a community garden in a neighborhood, entrepreneurs and gardeners have to address several limitations regarding space, tenure, soil, water and electricity, as well as a lack of tools or buildings. Vacant lots or vacant housing that are not owned by the gardeners and generally not created for gardening or animal keeping are often utilized. The conditions for agricultural production are often inadequate at the start of the project. Thus, the creation of production sites with suitable infrastructure and technology is a major topic of learning and innovation in UA. An interviewee describes this aspect as follows:

"It could be extremely innovative for a group or a community to organize themselves, take over a vacant lot that doesn't have access to water and figure out a way to get water to the site and electricity." (\#1)

In addition, interviewees describe experiencing joy when experimenting with technology and inventions. Novelties emerge by accident or by experimentation. Thereby, the specific interests of the innovation agents are more relevant as necessities or other external drivers. One interviewee explains the experimentation of one innovation agent of an urban farm as follows:

"But like his specialty is tearing things down and rebuilding them, so ( ... ) I guess largely

the project is all sorts of that, like who he is and what he's interested in." (\#15)

Innovations and novelties: In the field of production, technology and infrastructure, various new ideas and technical novelties are applied and tested by both business-oriented and non-profit UA. These novelties vary from very simple structures to complex technological solutions. The social and technical novelties mentioned in the interviews are listed in Table 4.

Table 4. Innovations and novelties in the learning area "production, technology and infrastructure".

\begin{tabular}{ll}
\hline \multicolumn{1}{c}{ Innovation/Novelty } & \multicolumn{1}{c}{ Description } \\
\hline Raised beds (\#7) & $\begin{array}{l}\text { Boxes from wood or other recycled materials filled with layers of } \\
\text { soil and residues of plants or compost to grow plants }\end{array}$ \\
\hline Moveable beds (\#2, \#8, \#3) & $\begin{array}{l}\text { Small box system, e.g., bakery boxes, or sacks filled with soil and } \\
\text { compost to grow plants; box systems are light weight and/or } \\
\text { easy to assemble }\end{array}$ \\
\hline Land trusts (\#2) & $\begin{array}{l}\text { Non-profit organization that buys land for conservation purpose; } \\
\text { land usage is regulated }\end{array}$ \\
\hline Hydroponics (\#15) & $\begin{array}{l}\text { Plant growing system in which plants grow in nutrition } \\
\text { solutions rather than soil }\end{array}$ \\
\hline
\end{tabular}


Table 4. Cont.

\begin{tabular}{|c|c|}
\hline Innovation/Novelty & Description \\
\hline Aquaponics (\#16, \#15) & $\begin{array}{l}\text { Combined system of hydroponic plant growing and raising fish; } \\
\text { fish waste is used as nutrition for plant growing }\end{array}$ \\
\hline Vermiculture (\#14) & System in which earthworms are reared and soil is built up \\
\hline Rainwater harvesting (\#3) & $\begin{array}{l}\text { System to harvest rainwater; the most simple form is a rain } \\
\text { barrel; most of the water is collected on a rooftop so that the } \\
\text { gradient can be explored for transportation }\end{array}$ \\
\hline Compost toilet (\#7) & Bio-chemical system that composts human feces \\
\hline Low-cost refrigerator (\#7) & Building operated with air conditioners to cool \\
\hline $\begin{array}{l}\text { Low-cost multipurpose } \\
\text { structure (\#3) }\end{array}$ & $\begin{array}{l}\text { Lightweight-construction building that can be used in different } \\
\text { ways, e.g., as a rain shelter, to store gardening tools or as } \\
\text { a meeting space }\end{array}$ \\
\hline Low-cost greenhouses (\#7) & Greenhouse from recycled materials, e.g., plastic tarpaulin \\
\hline Movable greenhouse $(\# 9, \# 14)$ & Greenhouse on rails, which is movable between the beds \\
\hline Bio-diesel (\#7) & Bio-diesel manufactured from waste oil from restaurants \\
\hline
\end{tabular}

Approaches and aims of the novelties: In general, the applied novelties in the area of production, technology and infrastructure tend to enhance or prepare basic conditions to practice UA and often exploit recycled materials. In most cases, additional goals are pursued. One of the interviewees describes this as follows:

"Some of the entrepreneurs ( ... ) who are trying something new they are doing it for different motivations. Some, because they are entrepreneurs, they want to create a viable business. Others, because their organization has certain goals (social justice, ecology), they want to promote through these innovations." (\#1)

Environmental issues are major concerns in this area of learning and innovation. Technology novelties are often created to save resources, such as water or additional plant nutrition, or are applied for such reasons. Innovation agents are aware of their responsibility for resources and compare their own actions to those of conventional agriculture or aquaculture. Moreover, new approaches are employed that are distinct from the conventional systems that have negative impacts. One interviewee makes the following statement about aquaponics:

"You know we're still raising fish, we still have a sort of a protein, we're still raising vegetables. But, I mean, even there with hydro plants, with growing plants in water, you have to have some chemical input. And most of the time, people use fertilize- hydro-based fertilizer. So by connecting these two things, you end up with this circle that avoids both of these problems in both of these otherwise separate methods of growing." (\#15)

One further general goal of most of the mentioned novelties is identifying inexpensive solutions. Structures and glasshouses have to be low in cost and efficient. Even the aspect of low financial input is often viewed as one of the most remarkable aspects of the new approaches, structures or technologies.

“Other people did it at the same time [invent rainwater harvesting systems] ( ... ) and then we are always trying to improve that system, and we are trying to make it cheaper. That's basically our main thing for any type of innovation." (\#3)

Intrinsic challenges of production, technology and infrastructure: Challenges arise from the fact that many people who are involved in UA are not trained gardeners, horticulturists or farmers. Some view $\mathrm{UA}$ as an experimental field and creative playground and do not consider their lack of professional 
knowledge to be problematic. Others perceive this lack of knowledge to be problematic and emphasize the need for more advisory services and professional support.

UA groups face intrinsic challenges if they must balance conflicting project goals that are not compatible or that are even contradictory, e.g., the applied practices should be environmentally friendly, but projects are financially restricted and must choose the least expensive option. In these situations, UA groups must make trade-offs and prioritize their different project goals. They often face a dilemma if they are aware of environmental practices that they would like to integrate, but cannot.

"But a lot of these things, ( . . ) that people are inventing are really not within the economic ability of most of the gardeners we work with. Like solar, we'd love to use more solar power, but it's so expensive. Most of the gardens don't have electricity at all, and if they have to use electricity for some purpose, they use a generator, which is definitely not very environmental. But yes, the solar and the storage and everything, it's so expensive, you know, there is really no cheap way to do it." (\#3)

\subsection{Markets and Demand}

Drivers of innovation and learning: UA is primarily operated by gardeners or new entrepreneurs within the cities, but there is no distribution network. When considering market and demand factors, learning processes primarily address how to make UA an economically self-sufficient or valuable business for entrepreneurs. Interviewees stress the importance of gaining experience with market demands and developing a sense of the non-food co-products, which can be surprising. An urban farm manager from Philadelphia experienced how "unexpected" income sources were activated when consumers began to appreciate their co-products: "We sell more t-shirts that say 'Honey from the hood' than we do honey" (\#7). Additionally, general access to markets is a major field of learning and innovation and is a basic necessity for income generation and financial success. This area of learning includes permission, distribution pathways and knowledge about consumer demands. Furthermore, non-profit, community-orientated urban gardeners must build up networks in the neighborhood to distribute surplus products, as one interviewee stresses:

"Right now the farm is producing much more than we know what to do with. We actually don't have enough ( . . ) distribution ( ... )." (\#10)

Innovations and novelties: Concerning markets and demands, new ideas and approaches are organizational processes and new products. Especially in the learning area of distribution and food supply, new relationships between consumers and producers are tested. The novel concepts mentioned in the interviews are listed in Table 5.

Table 5. Innovations and novelties in the learning area "markets and demand".

\begin{tabular}{cl}
\hline Innovation/Novelty & \multicolumn{1}{c}{ Description } \\
\hline Bundles of herbs (\#1) & $\begin{array}{l}\text { Service innovation in which teenagers from the } \\
\text { community deliver bundled herbs for tea or remedies to } \\
\text { seniors in the neighborhood }\end{array}$ \\
\hline $\begin{array}{c}\text { Community-supported agriculture (CSA) } \\
(\# 15, \# 7, \# 17)\end{array}$ & $\begin{array}{l}\text { Model wherein a group of consumers buys the harvest } \\
\text { from the producer in advance and gets a share of the } \\
\text { harvest during the season }\end{array}$ \\
\hline Three-tier approach (\#17) & $\begin{array}{l}\text { Income model in which one part of the harvest is } \\
\text { donated, a second part is sold at a reduced rate and } \\
\text { a third part is sold to the highest bidder }\end{array}$ \\
\hline
\end{tabular}

Approaches and aims of the novelties: The most relevant goal is to generate revenues by obtaining access to markets and learning about consumer demands. Additionally, social goals are met. Some interviewees mentioned the relevance of distributing food not only to people who pay the 
most, but also to low-income groups or other disadvantaged people. Thus, collaborative consumption patterns, such as donations and bartering within networks in the neighborhood, are often practiced. Sharing knowledge about products and growing practices with food distribution is a further social goal of applying the novelties in the learning area of markets and demand. Education is distributed with the food, while, e.g., specific medical herbs are bundled or the producer explains how to prepare certain vegetables or fruits.

Intrinsic challenges of markets and demand: The distribution patterns of UA enterprises differ from those of conventional horticultural enterprises, and the existing rural approaches cannot simply be imposed on UA. As one interviewee describes:

"That requires a different form of distribution of the produce if you are trying to sell it compared with a conventional garden, where you can just have a farm stand in front." (\#1)

\subsection{Social Acceptance and Cultural Learning}

Drivers of innovation and learning: UA is a relatively new activity within (some) cities and raises land use conflicts. When a group of gardeners or an entrepreneur starts a garden or farm project in an unfamiliar neighborhood, conflicts or misunderstandings arise because of different cultural or educational backgrounds or different value judgments. Many gardeners complain that a direct impact of these differences is vandalism or the theft of vegetables. Thus, the area of learning in terms of social acceptance in the neighborhood is a major topic in UA regarding both business-oriented and non-profit UA operators. In addition, social acceptance on a civic level is frequently mentioned in the interviews. UA operators are confronted with a bureaucratic system that does not know the category of UA and is not familiar with the needs and values of the gardeners. An NGO representative reports communication problems between activists and public authorities, as follows:

"If you are the typical bureaucrat in the agency that doesn't deal with community gardens at all and don't have any idea what it is, you don't want to get that phone call. So, we have been working with them. When people contact them, they tell them to call us and then we can act as an intermediary." (\#3)

Innovations and novelties: Most of the applied novelties in the field of UA are organizational approaches that spread information, provide support and offer participation in progress, knowledge and the value system. The number of people involved ranges from a few to many within citywide networks. Table 6 lists the novelties that were mentioned in the interviews.

Table 6. Innovations and novelties in the learning area "social acceptance and cultural learning".

\begin{tabular}{cl}
\hline Innovation/Novelty & \multicolumn{1}{c}{ Description } \\
\hline Community management system $(\# 3)$ & $\begin{array}{l}\text { Support program for gardeners that provides extension } \\
\text { services and support if they form a functioning group } \\
\text { with an elected representative }\end{array}$ \\
\hline Urban agriculture network (\#13) & $\begin{array}{l}\text { Citywide network of urban agriculture activists, from } \\
\text { community gardeners to social entrepreneurs, who } \\
\text { advise municipal departments or publish guidelines }\end{array}$ \\
\hline Train the trainers (\#2, \#3) & $\begin{array}{l}\text { Snowball concept, in which people are trained by } \\
\text { an organization and then are obligated to share their } \\
\text { knowledge with other gardeners, who are then obliged } \\
\text { to pass the knowledge on to the next gardener }\end{array}$ \\
\hline Open farm $(\# 7, \# 14, \# 15)$ & $\begin{array}{l}\text { A concept that gives visitors the possibility to tour the } \\
\text { farm, help as a volunteer or feed farm animals }\end{array}$ \\
\hline
\end{tabular}

Approaches and aims of the novelties: All of the interviewees from business-oriented farms and non-profit organization stress the importance of cooperation and communication for acceptance. 
"So they were pushing people to come together and communicate" (\#2). The various forms of network building within a group of gardeners and gardeners' offers to present information to the neighborhood and other interested people are often described as "community building" (\#3,\#1). Community building can be an aim of UA projects, but it is more often considered as a precondition for project development and community-driven change. One interviewee describes community building as follows:

“ $(\ldots)$ there are really amazing social benefits of having a collectively managed space where the people essentially didn't know each other at the beginning and then they have this joint goal $(\ldots)$ people who end up taking care of the street trees and being the neighborhood watch and joining the community board and getting involved in politics, and it really builds the community." (\#3)

Interviewees consider accepting new behaviors in UA and changing people's minds as aspects of creating and applying novelties. A garden program representative explains these cultural learning processes using the example of urban chickens:

"Keeping chickens was always thought of as something really bad. But now, it's the opposite. Now, they are like "Oh, it's great, and there are fresh eggs" ( ... ) and the kids love it. So changing people's minds is part of the innovation." (\#3)

Intrinsic challenges of social acceptance and cultural learning: One major challenge is potential conflicts between activists and public authorities, which could negatively affect the entire UA community. Because some activists perceive public authorities and administration as being overly hesitant, their approach is to become increasingly radical and to aggressively establish projects on vacant public land, which results in conflict with public authorities. Consequently, these behaviors create tensions among the different actors in the UA movement. Although most activists perceive negotiating with public authorities to be part of the overall learning process, they find it difficult to exercise patience because they want fast results.

"I think that they [an activist group] ran about the process really wrong. They aggravated a whole lot of people because they put signs on all these vacant lots that belong to different city agencies, with the contact information $(\ldots)$ and so people are calling, $(\ldots)$ asking if they can use this land. And it's a little aggressive, their sign is like 'This is your land', it's a little occupy-ish." (\#3)

A further challenge is the different values of the members of one UA project. When younger gardeners or gardeners with different cultural or educational backgrounds participate in existing garden projects or found a new garden close to settled gardeners, conflicts about the aims of the gardens and the mechanism behind the community arise. Certainly, UA raises major media attention and is perceived as trendy; thus, individuals with different interests are attracted to UA.

“ $(\ldots)$ and in some gardens, you see a conflict between the old guard and the new ones who just want more like my place to enjoy, my pretty garden. And the others were more forced to facilitate progress in the neighbourhood." (\#2)

An additional challenge for UA groups is psychologically managing outside hostility and aversion. Even if UA operators perceive that UA makes a valuable contribution to improving the residents' quality of life, the neighborhood does not necessarily support UA. Individuals who are involved in UA projects must defeat these psychological challenges and overcome periods of hopelessness when confronted with criticism or even vandalism or violence. These challenges can drive people to quit, as an urban farm manager experienced with the farm's co-founder:

"He couldn't take it here; the kids just threw rocks at us. Stuff like that. When we were shoveling snow off of the greenhouse, they repelled us with snowballs. They stole everything that we had, everything. ( . . ) He wasn't cut out for that kind of thing." (\#7) 
UA groups also face the challenge of a lack of commitment and responsibility. Initially, it is difficult to find people to take responsibility for and commit to the gardens rather than "just participating". Then, due to members' unreliability, many UA groups cannot effectively organize to access resources and take advantage of offers developed to support them.

One further challenge for UA practitioners is the issue of the exclusion of people. Community gardeners or entrepreneurs building high-technology rooftop farms constitute specific communities that support and operate the project on various levels (e.g., within the neighborhood or the city or beyond the city) and in terms of various issues. Such networks consist of weak and strong ties, this often includes a specific type of communication and values and often exists between persons of the same class or race. As one interviewee stresses, networks involve the risk of exclusion:

"In part, while networks are really beneficial in terms of spreading information and helping people to learn, they can be exclusionary as well." (\#1)

Community building within a network of a community garden includes the risk to exclude, e.g., people from the neighborhood who are not involved in the activities of the garden. Business-oriented rooftop farms include the risk to exclude, e.g., people who cannot afford buying vegetables grown on rooftops.

\section{Discussion}

Learning and innovation in UA occur predominantly in four areas, namely, "financing and funding", "production, technology and infrastructure", "markets and demands", and "social acceptance and cultural learning". Thereby, business-oriented operators, as well as non-profit gardeners mentioned novelties in the full range of the four areas of learning and innovation. An obvious preference for creating and applying novelties in one certain area is not identifiable from the interviews for either group. Certainly, most of the mentioned novelties in the area of "markets and demands" are more relevant for entrepreneurial UA, while novelties in the area of "social acceptance and cultural learning" are more often mentioned by representatives of non-profit UA.

Practitioners often learn to remedy the perceived restricting or problematic situation by adopting or generating novelties. Individual learning processes, as described by Brunori et al. 2011, occur [35]. Thus, some of the described novelties are an expression of the limited conditions that the practitioners face, and some are a result of enjoying experimentation. Additionally, in the case the project has an internet representation, analyzing the websites of the interviewed entrepreneurs and gardeners pointed to the fact that novelties seem to be relevant for marketing reasons, especially in the case of entrepreneurial UA.

UA operators prefer simple and low-cost solutions that meet basic needs, especially financing and funding, but also production and infrastructure. Many of the described novelties were developed due to the awareness of depleted resources and the common wish for active improvement toward the three dimensions of sustainability. Applying novelties meets the goal of actively engaging in change toward the various dimensions of sustainability.

\subsection{Dimensions of Sustainability and Diffusion Possibilities}

Environmental goals are met by developing and refining technological solutions in the learning area "production, technology and infrastructure". While hydroponic or aquaponics technologies, as well as rooftop farms are regarded as promising approaches that save water, reduce environmental impacts [54] and potentially contribute to food security and urban diversity [55], a substantial amount of construction materials and electricity are needed to install and operate such technologies. Currently, low-cost solutions, such as rainwater harvesting and irrigation systems, which were developed due to practical needs and under limited budgets, may have a greater positive environmental impact than high-technology innovations, such as, e.g., Sanye-Mengual et al. 2015 demonstrated in the case of rooftop production. They examined that food products from a low-tech rooftop garden had lower 
environmental impacts than those from high-tech rooftop greenhouses [54]. Certainly, one potential disadvantage of technology-extensive solutions is that they are barely transferable because they are one-way solutions for certain local issues in the specific context of the garden or farm and utilize available materials. It is more difficult to implement such solutions in another garden without having the same materials available. From the perspective of learning and innovation, such solutions are relevant for the implementation and establishment of environmentally-sound practices and shared knowledge about the sustainable use of resources, such as water, and about closing resource cycles by using compost or the introduction of a new type of use for existing materials, such as bakery boxes for raised beds. Regarding the novelties as product innovations, successful diffusion may depend on the possibility to substitute the materials used.

Social goals are met with organizational solutions in the learning areas of "social acceptance and cultural learning" and "markets and demands". These solutions' positive effects on society result predominantly from cooperation and involving and interacting with people residing in the neighborhood. Novelties appear to be negotiations of different perspectives and mostly have a democratic character. A major motive of the described novelties is to educate and increase the knowledge of involved, neighboring and otherwise affected people. Thus, an aim is to ensure that knowledge persists within a network or between the different interested groups, and this goal is often at the center of the organizational novelty. Furthermore, novelties aim to change people's mindset rather than to simply spread information. These gains in changes of knowledge and mindset can lead to a change in lifestyle (such as in terms of changing diets or general consumption patterns), as well as on the individual and on the community level.

From the perspective of innovation and learning, solutions targeting the social dimension of sustainability are highly dynamic and transferable to other localities and projects. Successful diffusion may depend on the precise description and awareness of the relevant aspects of the organization, the relationships between the involved people and their dependencies.

Independent from the intrinsic aim to create a viable business or to gain financial resources that lead to the application of novelties in the area of "financing and funding", economic goals lead to organizational novelties in the area of "markets and demands". Approaches addressing changes in relationships and interactions between consumers and producers imply an alternative understanding of economy. Elements of collaborative consumption [56] or the sharing economy become visible within the new concepts and novelties. The diffusion of these new concepts may depend on their impacts on consumers and producers and the society as a whole and whether the benefits that the groups receive will overbalance the disadvantages and contribute to sustainability, welfare and an enhanced quality of life.

\subsection{Potential for Societal Change}

Thereby, the learning area of "markets and demands" might have the most potential to contribute to societal change. Novelties in this field are attempts to unite the demands of the consumer groups with the economic aims of the producer in the case of business-oriented UA. For the novelties mentioned in the interviews, or similar approaches in the context of alternative food networks (AFN) [57], dimensions of justice and trust based on knowledge become important. Thereby, the understanding of the role of consumers and producers in the AFN differs from that in the current conventional agri-food system. Applying the new models, networks between consumers and producers and when consumers become prosumers open social learning processes toward societal transition, as described in terms of solidary purchase groups [36]. Additionally, novelties revise the understanding of economic activity. While in the traditional understanding, markets and interventions regulate prices, quality and quantities, in the sharing economy, these elements are driven by the promotion of the common use and provision of goods. This could be seen as a signal for a paradigm change in a wider context. Certainly, new approaches in the learning area "markets and demands" include the current risk of 
excluding certain population groups. As discussed in the literature, local food movements are tending to distribute their products to relatively privileged customers [58-60].

Additionally, novelties regarding acceptance and cultural change have the potential to contribute to societal transitions. Community gardens, as one important type of UA, represent values, such as the common use of goods and the empowerment of people residing in the neighborhood $[4,37]$. The application of novelties in the area "social acceptance and cultural learning" provides opportunities for social learning processes between the gardeners and operators of UA, on the one hand, and people residing in the neighborhood, the municipality or the urban population in general, on the other hand, as a precondition for societal change.

However, most of the novelties mentioned in the interviews are a result of individual learning processes [35]. Especially, novelties concerning "production, technology and infrastructure", such as indoor farming or aquaponics, affect production rather than societal change. Farmers or gardeners decide to use new technologies, which might have a positive impact on the environment. Positive social or economic effects highly depend on the concept of operation and whether it considers the inclusion of consumers or people residing in the neighborhood [33].

\subsection{Methodological Aspects}

The results concerning the intrinsic challenges demonstrate the relevance of acceptance and cultural learning. In nearly every interview, the interviewee raised the issue and discussed unsolved intrinsic challenges. Compared to the area of "production, technology and infrastructure", in which many novelties were reported, the area of "social acceptance and cultural learning" has a relatively small number of novelties, which is surprising. Based on these results, one could assume that there are only a few novel approaches regarding these issues. However, in the recent literature about community gardens or UA in general, several studies provide evidence on novelties comparable to those mentioned in the interviews $[47,61,62]$. A better explanation seems to be the narrow understanding of the terms novelty and innovation. Before the interviews began, we explained the wide and open meaning of the terms used in the study to the interviewees. Most of the interviewees may still follow their own understanding. In the common understanding, technological products refer to innovation. In terms of acceptance and cultural learning, organizational solutions are especially applicable. It is possible that the interviewees were not aware of such solutions when they spoke about innovations and that they forgot to mention further innovations in terms of "social acceptance and cultural learning". It is more difficult to operationalize one's own action and to identify this action as a novelty.

From a methodological perspective, a relatively small group of interviews was conducted and analyzed because UA practitioners' willingness to participate in such interviews has decreased; specifically, UA leaders have become tired of repetitive questioning. This may become a serious concern in future research on UA. For our results, the relatively small number of analyzed interviews is not problematic. We matched our findings and the novelties mentioned in the interviews with those in the literature, and the results demonstrated a similar range of novelties, from social to economic to ecological, from organizational to technical and from low-cost to cost-intensive novelties.

\subsection{Contributing to the State of the Art}

Thus, our results complement and deepen the debate. In most examples of best practices and studies on technological innovations in UA, which represent a large amount of the recent literature, the focus is a certain novelty or innovation, e.g., rooftop farming [25,63], and its (potential) impacts on society [5,32]. In most of these studies, the relevance of the system of UA and the specific capacity and knowledge of the innovation agents in UA are low. By contrast, the current study focuses on the system of UA, its internal drivers and its intrinsic challenges. Thereby, this study is a consolidation and an addition to the studies of Cohen and Reynolds (2014) and Pfeiffer et al. $(2014)[9,13]$. Some of the novelties mentioned by the interviewees in this study are reactions to resource needs, as Cohen and Reynolds (2014) have examined, e.g., limited financial resources or unclear guidelines for farmer 
markets and for selling produce. One of the authors' merits is describing the disparities among urban agriculture practitioners based on race and class [13], as the current study confirms being an ongoing intrinsic challenge. Pfeiffer et al. (2014) focus on the context of urban production environments and innovations similar to the area of "production, technology and infrastructure". Their findings picture a'similar range of challenges and innovations as this study examined, focusing on the area of production and describing it more in detail [9]. The current study additionally involves organizational and social innovations from other areas of learning and innovation as "financing and funding", "markets and demands" and "social acceptance and cultural learning". The results enhance the understanding about the learning areas that UA innovation agents experiment with and how the applied novelties contribute to overcoming limitations and sustainability. We analyzed the drivers of innovation, and our results underpin the findings of other studies, which explored a direct correlation between resource needs in urban settings and innovation in UA [9,64]. Additionally, the results include preferences and interests of the UA innovation agents as drivers for innovation. To generalize and transfer the results to other regions, the context of the study, i.e., the U.S. and its specific urban and societal settings and interrelations, must be taken into account.

\section{Conclusions}

Investigating the most relevant areas of learning and innovation, this study explored activities in the areas of "financing and funding", "production, technology and infrastructure", "markets and demands" and "social acceptance and cultural learning", describing the drivers of innovations and occurring novelties, as well as intrinsic challenges that have not been met by the innovations yet. Learning occurs predominantly at an individual level, as UA operators identify obstacles and problems in their own context and search for solutions. Most novelties, technical, as well as organizational, are applied to overcome the inadequate conditions for practicing UA in the urban setting. Furthermore, learning and innovation are driven by enjoying experimentation and the goal of contributing toward sustainability. As the study examined, novelties applied in UA include approaches to enhancing the social, ecological and economic impact of practicing agriculture within urban areas, holding the potential to contribute to sustainability. Beyond, some of the novelties, especially from the learning areas "markets and demands" and "social acceptance and cultural learning", have the potential to contribute to societal transition and provide opportunities for social learning processes. Certainly, novelties from the area "markets and demands" include the risk to prefer well-educated and middle-class consumers.

Acknowledgments: We wish to express our greatest thanks to all our interviewees, who shared their knowledge and fruitfully collaborated with us throughout the entire research process. Funding from the Federal Ministry of Education and Research, Germany (BMBF) has supported this work through the project INNSULA (Funding Code FKZ 16I1623). The Leibniz Centre for Agricultural Landscape Research (ZALF) is institutionally funded by the Federal Ministry of Food, Agriculture and Consumer Protection (BMELV) and the Ministry for Science, Research and Culture of the State of Brandenburg (MWFK).

Author Contributions: Ina Opitz, Regine Berges, Kathrin Specht, Annette Piorr and Rosemarie Siebert conceived of and designed the study. Ina Opitz and Regine Berges conducted the interviews. Kathrin Specht and Ina Opitz analyzed the data. Ina Opitz and Kathrin Specht wrote the paper.

Conflicts of Interest: The authors declare no conflict of interest.

\section{Abbreviations}

The following abbreviations are used in this manuscript:
AFN
Alternative food network
BMBF
Federal Ministry of Education and Research, Germany
BMELV
Federal Ministry of Food, Agriculture and Consumer Protection, Germany 


$\begin{array}{ll}\text { CSA } & \text { Community-supported agriculture } \\ \text { MWFK } & \text { Ministry for Science, Research and Culture of the State of Brandenburg } \\ \text { UA } & \text { Urban agriculture } \\ \text { ZALF } & \text { Leibniz Centre for Agricultural Landscape Research }\end{array}$

\section{References}

1. Bohn, K.; Viljoen, A. The edible city: Envisioning the continuous productive urban landscape (CPUL). Field Free J. Archit. 2010, 4, 149-161.

2. Pearson, L.J.; Pearson, L.; Pearson, C.J. Sustainable urban agriculture: Stocktake and opportunities. Int. J. Agric. Sustain. 2010, 8, 7-19. [CrossRef]

3. Lydecker, M.; Drechsel, P. Urban agriculture and sanitation services in Accra, Ghana: The overlooked contribution. Int. J. Agric. Sustain. 2010, 8, 94-103. [CrossRef]

4. Saldivar-Tanaka, L.; Krasny, M.E. Culturing community development, neighborhood open space, and civic agriculture: The case of Latino community gardens in New York City. Agric. Hum. Values 2004, 21, 399-412. [CrossRef]

5. Thomaier, S.; Specht, K.; Henckel, D.; Dierich, A.; Siebert, R.; Freisinger, U.B.; Sawicka, M. Farming in and on urban buildings: Present practice and specific novelties of Zero-Acreage Farming (ZFarming). Renew. Agric. Food Syst. 2015, 30, 43-54. [CrossRef]

6. Smit, J.; Nasr, J.; Ratta, A. Cities that feed themselves. In Urban Agriculture: Food, Jobs and Sustainable Cities, 2001 ed.; published with permission from the United Nations Development Programme; Smit, J., Nasr, J., Ratta, A., Eds.; The Urban Agriculture Network, Inc.: Washington, DC, USA, 2001; pp. 1-29. Available online: http:/ / www.jacsmit.com/book.html (accessed on 8 April 2016).

7. Mougeot, L.J.A. Urban agriculture: Definition, presence, potentials and risks. In Growing Cities Growing Food-Urban Agriculture on the Policy Agenda, 2000 ed.; Bakker, N., Dubbeling, M., Gündel, S., Sabel-Koschella, U., De Zeeuw, H., Eds.; DSE: Feldafing, Germany, 2000; pp. 1-42.

8. Opitz, I.; Berges, R.; Piorr, A.; Krikser, T. Contributing to food security in urban areas: Differences between urban agriculture and peri-urban agriculture in the Global North. Agric. Hum. Values 2015. [CrossRef]

9. Pfeiffer, A.; Silva, E.; Colquhoun, J. Innovation in urban agricultural practices: Responding to diverse production environments. Renew. Agric. Food Syst. 2014, 30, 79-91. [CrossRef]

10. Ackerman, K. The Potential for Urban Agriculture in New York City-Growing Capacity, Food Security, and Green Infrastructure, 1st ed.; Columbia University: New York, NY, USA, 2011; Available online: http://urbandesignlab.columbia.edu/files/2015/04/4_urban_agriculture_nyc.pdf (accessed on 7 April 2016).

11. Nolasco, J. Sustainable Water Management for Urban Agriculture; Pacific Institute and Planting Justice: Oakland, CA, USA, 2011. Available online: http://www.pacinst.org/reports/success_stories/sustainable_ water_management_for_urban_agriculture.pdf (accessed on 8 April 2016).

12. Cabannes, Y. Financing and Investment for Urban Agriculture. In Cities Farming for the Future-Urban Agriculture for Green and Productive Cities, 1st ed.; Van Veenhuitzen, R., Ed.; RUAF Foundation: Ottawa, ON, Canada; Silang, Philippines, 2006; pp. 87-123.

13. Cohen, N.; Reynolds, K. Resource needs for socially just and sustainable urban agriculture system: Lessons from New York City. Renew. Agric. Food Syst. 2014, 30, 103-114. [CrossRef]

14. Schmelzkopf, K. Urban community gardens as contested space. Geogr. Rev. 1995, 85, 364-381. [CrossRef]

15. Ottmann, M.M.A.; Maantay, J.A.; Grady, K.; Fonte, N.N. Characterization of Urban Agricultural Practices and Gardeners' Perceptions in Bronx Community Gardens, New York City. Cities Environ. 2012, 5, 13.

16. Berges, R. Innovations in Urban Agriculture and their Impacts: A study tour to the USA. Urban Agric. Mag. 2014, 28, 35-37.

17. Van Veenhuizen, R. Stimulating Innovation in Urban Agriculture. Urban Agric. Mag. 2007, 19, 1-2,7.

18. Brommer, M.; Critchley, W. Innovative Wastewater Recycling in an Indian village: Linking the rural with the urban. Urban Agric. Mag. 2007, 19, 16.

19. Keraita, B.; Drechsel, P.; Agyekum, W.; Hope, L. In Search of Safer Irrigation Water for Urban Vegetable Farming in Ghana. Urban Agric. Mag. 2007, 19, 17-19.

20. Sullivan, C.; Hallaran, T.; Sogorka, G.; Weinkle, K. An evaluation of conventional and subirrigated planters for urban agriculture: Supporting evidence. Renew. Agric. Food Syst. 2015, 30, 55-63. [CrossRef] 
21. Van Beek, S.; Rutt, R.L. Cleaning, Greening and Feeding Cities: Local Initiatives in Recycling Waste for Urban Agriculture in Kampala, Uganda. Urban Agric. Mag. 2007, 19, 36-38.

22. Tefera, B.; Tikubet, G. Solid Waste Recycling in Addis Ababa, Ethiopia: Making a business of waste management. Urban Agric. Mag. 2007, 19, 41-43.

23. Ranasinghe, T.T. Family Business Garden as an Innovative Enterprise in Urban Agriculture. Urban Agric. Mag. 2007, 19, 22-24.

24. Christensen, R. SPIN Farming: Improving revenues on sub-acre plots. Urban Agric. Mag. 2007, 19, $25-26$.

25. Rodriguez, O. London Rooftop Agriculture: A Preliminary Estimate of Productive Potential. Master's Thesis, Welsh School of Architecture, Cardiff, UK, 2009.

26. Cerón-Palma, I.; Sanyé-Mengual, E.; Oliver-Solà, J.; Montero, J.-I.; Rieradevall, J. Barriers and opportunities regarding the implementation of rooftop Eco.Greenhouses (RTEG) in mediterranean cities of Europe. J. Urban Technol. 2012, 19, 87-103. [CrossRef]

27. Sanyé-Mengual, E.; Cerón-Palma, I.; Oliver-Solà, J.; Montero, J.I.; Rieradevall, J. Environmental analysis of the logistics of agricultural products from roof top greenhouses in Mediterranean urban areas: Life cycle assessment of the logistics of agricultural products. J. Sci. Food Agric. 2013, 93, 100-109. [CrossRef] [PubMed]

28. Sanyé-Mengual, E.; Oliver-Solà, J.; Montero, J.I.; Rieradevall, J. An environmental and economic life cycle assessment of rooftop greenhouse (RTG) implementation in Barcelona, Spain-Assessing new forms of urban agriculture from the greenhouse structure to the final product level. Int. J. Life Cycle Assess. 2015. [CrossRef]

29. Despommier, D. The Vertical Farm: Feeding the World in the 21st Century, 1st ed.; Thomas Dunne Books: New York, NY, USA, 2010.

30. Fischetti, M. Growing Vertical. Sci. Am. 2008, 18, 74-78. [CrossRef]

31. Hae-Dong, K. For sustainable cities: Meaning and Possibility of Vertical Farming. Space Mag. 2009, 488, 124-127.

32. Specht, K.; Siebert, R.; Hartmann, I.; Freisinger, U.B.; Sawicka, M.; Werner, A.; Thomaier, S.; Henckel, D.; Walk, H.; Dierich, A. Urban agriculture of the future: An overview of sustainability aspects of food production in and on buildings. Agric. Hum. Values 2014, 31, 33-51. [CrossRef]

33. Specht, K.; Siebert, R.; Thomaier, S. Perception and acceptance of agricultural production in and on urban buildings (ZFarming): A qualitative study from Berlin, Germany. Agric. Hum. Values 2015. [CrossRef]

34. Van der Ploeg, J.D.; Bouma, J.; Rip, A.; Rijkenberg, F.H.; Ventura, F.; Wiskerke, J. On Regimes, Novelties, Niches and Co-Production. In Seeds of Transition: Essays on Novelty Production, Niches and Regimes in Agriculture, 1st ed.; Wiskerke, J., van der Ploeg, J.D., Eds.; Van Gorkum Ltd.: Assen, The Netherlands, 2004; pp. 1-29.

35. Brunori, G.; Rossi, A.; Malandrin, V. Co-Producing Transition: Innovation Processes in Farms Adhering to Solidarity-based Purchase Groups (GAS) in Tuscany, Italy. Int. J. Sociol. Agric. Food 2011, 18, $28-53$.

36. Brunori, G.; Rossi, A.; Guidi, F. On the New Social Relations around and beyond Food. Analysing Consumers' Role and Action in Gruppi di Acquisto Solidale (Solidarity Purchasing Groups): Gruppi di Acquisto Solidale. Sociol. Rural 2012, 52, 1-30. [CrossRef]

37. Armstrong, D. A survey of community gardens in upstate New York: Implications for health promotion and community development. Health Place 2000, 6, 319-327. [CrossRef]

38. Pourias, J.; Aubry, C.; Duchemin, E. Is food a motivation for urban gardeners? Multifunctionality and the relative importance of the food function in urban collective gardens of Paris and Montreal. Agric. Hum. Values 2015. [CrossRef]

39. Draper, C.; Freedman, D. Review and Analysis of the Benefits, Purposes, and Motivations Associated with Community Gardening in the United States. J. Community Pract. 2010, 18, 458-492. [CrossRef]

40. Cohen, N.; Reynolds, K.; Sanghvi, R. Five Borough Farm: Seeding the Future of Urban Agriculture in New York City; Chou, J., Ed.; Design Trust for Public Space: New York, MY, USA, 2012. Available online: http:/ / www.fiveboroughfarm.org/resources (accessed on 8 April 2016).

41. Müller, C. Intercultural Gardens-Urban Places for Subsistence Production and Diversity. Ger. J. Urban Stud. 2007, 46, 1-6.

42. Baker, L. Tending cultural landscapes and food citizenship in Toronto's community gardens. Geogr. Rev. 2004, 94, 305-325. [CrossRef]

43. United Census Bureau. "QuickFacts". Available online: http://www.census.gov/quickfacts/table/ PST045215/00 (accessed on 8 April 2016). 
44. Taylor, J.R.; Lovell, S.T. Mapping public and private spaces of urban agriculture in Chicago through the analysis of high-resolution aerial images in Google Earth. Landsc. Urban. Plan. 2012, 108, 57-70. [CrossRef]

45. Vitiello, D.; Nairn, M. Community Gardening in Philadelphia. 2008 Harvest Report; Penn Planning and Urban Studies; University of Philadelphia: Philadelphia, PA, USA, 2009. Available online: http://www.farmlandinfo.org/sites/default/files/Philadelphia_Harvest_1.pdf (accessed on 8 April 2016).

46. Castillo, S.R.; Winkle, C.R.; Krauss, S.; Turkewitz, A.; Silva, C.; Heinemann, E.S. Regulatory and other barriers to urban and peri-urban agriculture: A case study of urban planners and urban farmers from the greater Chicago metropolitan area. J. Agric. Food Syst. Community Dev. 2013, 3, 155-166. [CrossRef]

47. Schmelzkopf, K. Incommensurability, land use, and the right to space: Community gardens in New York. Urban Geogr. 2002, 23, 323-343. [CrossRef]

48. Ryan, B.D. Rightsizing shrinking cities: The urban design dimension. In The City after Abandonment, 1st ed.; Dewar, M.E., Thomas, J.M., Eds.; University of Pennsylvania Press: Philadalphia, PA, USA, 2012; pp. 268-288.

49. Hyra, D.S. The New Urban Renewal: The Economic Transformation of Harlem and Bronzeville, 1st ed.; University of Chicago Press: Chicago, IL, USA, 2008.

50. Kremer, P.; DeLiberty, T.L. Local food practices and growing potential: Mapping the case of Philadelphia. Appl. Geogr. 2011, 31, 1252-1261. [CrossRef]

51. Patton, M.Q. Qualitative Research and Evaluation Methods, 3rd ed.; Sage Publications: Thousands Oaks, CA, USA, 2002.

52. MaxQDA. The Art of Data Analysis 2014. Available online: http:/ /www.maxqda.com/legalinfo (accessed on 8 April 2016).

53. Kuckartz, U. Qualitative Text Analysis. A Guide to Methods, Practice and Using Software, 1st ed.; Sage Publications: Thousand Oaks, CA, USA, 2014.

54. Sanye-Menual, E.; Orsini, F.; Oliver-Sola, J.; Rieradevall, J.; Montero, J.I.; Gianquinto, G. Techniques and crops for efficient rooftop gardens in Bologna, Italy. Agron. Sustain. Dev. 2015, 35, 1477-1488.

55. Orsini, F.; Gasperi, D.; Marchetti, L.; Piovene, C.; Draghetti, S.; Ramazotti, S.; Bazzocchi, G.; Gianquinto, G. Exploring the production capacity of rooftop gardens (RTGs) in urban agriculture: The potential impact on food and nutrition security, biodiversity and other ecosystem services in the city of Bologna. Food Sec. 2014, 6, 781-792. [CrossRef]

56. Botsman, R.; Rogers, R. What's Mine Is Yours: How Collaborative Consumption Is Changing the Way We Live; Collins: London, UK, 2011.

57. Renting, H.; Schermer, M.; Rossi, A. Building Food Democracy: Exploring Civic Food Networks and Newly Emerging Forms of Food Citizenship. Int. J. Sociol. Agric. Food 2012, 19, $289-307$.

58. The Guardian. Is Urban Farming Only for Rich Hipsters? Available online: http:/ /www.theguardian.com/ sustainable-business/2016/feb/15/urban-farming-rich-hipsters-food-affordability-inequality (accessed on 8 April 2016).

59. Guthman, J. Fast food/organic food: Reflexive tastes and the making of "yuppie chow". Soc. Cult. Geogr. 2003, 4, 45-58. [CrossRef]

60. Guthman, J. Bringing food to others: Investigating the subjects of alternative food practice. Cult. Geogr. 2008, 15, 431-447. [CrossRef]

61. Eizenberg, E. The changing meaning of community space: Two models of NGO management of community gardens in New York City. Int. J. Urban Reg. Res. 2011. [CrossRef]

62. Alaimo, K.; Reischl, T.; Ober Allen, J. Community gardening, neighborhood meetings, and social capital. J. Community Psychol. 2010, 38, 497-514. [CrossRef]

63. Sanyé-Mengual, E.; Cerón-Palma, I.; Oliver-Solà, J.; Montero, J.I.; Rieradevall, J. Integrating Horticulture into Cities: A Guide for assessing the implementation potential of Rooftop Greenhouses (RTGs) in industrial and logistics parks. J. Urban. Technol. 2015. [CrossRef]

64. Prain, G.; de Zeeuw, H. Enhancing Technical, Organisational and Institutional Innovation in Urban Agriculture. Urban Agric. Mag. 2007, 19, 9-15.

(C) 2016 by the authors; licensee MDPI, Basel, Switzerland. This article is an open access article distributed under the terms and conditions of the Creative Commons Attribution (CC-BY) license (http://creativecommons.org/licenses/by/4.0/). 